\title{
Of Golden Feathers and Light Reading: Guido Gozzano's "Piumadoro e Piombofino."
}

\section{Cristina MAZZOni}

Summary: Guido Gozzano's "Piumadoro e Piombofino" (1909) is a text light in terms of genre (a literary fairy tale), style (six short, poetic segments, rich in repetitions and fantastic elements), and, most obviously, content (the eponymous protagonist suffers from a spell that has made her body weightless). A comparison between Gozzano's tale and its two literary antecedents-George MacDonald's "The Light Princess" and Luigi Capuana's "Piuma d'oro"-reveals a play with citations and literary models analogous to that found in Gozzano's poetry as well as the addition of significant social reflections: Gozzano's protagonist overcomes the hurdles of a difficult age (embodied in the tasks of the Fairy of Adolescence); she saves the man she loves rather than the other way around; she starts out at the lowest social rank and becomes, in the end, a queen.

Literary fairy tales are a hybrid genre. They do not quite belong to folklore, though some pretend they do, and in the literary world they remain marginal-despite the recent growth in size and respectability of the field of children's literature. Inspired in their choice of themes and style by folktales, literary fairy tales imitate in many ways those traditional narratives that claim no author and that declare themselves to be the property of a people's imagination. However, unlike anonymous folktales, literary fairy tales are the accomplished product of professional writers who reveal the work of their hand to varying degrees: while some authors hide behind the mask of objective transcriber, others make no secret of their active role in shaping their text. Whatever the author's approach, however, there can be no sharp dividing line between folktales and literary fairy tales, all the more so because contemporary western culture accesses folk tales primarily through their transcription by professional writers. Thus, although the brothers Grimm and Italo Calvino, to mention the authors of two of the best known collections, claim to be recording the words of their folk informants or written sources their tales bear each author's characteristic stamp and the stamp of his age and culture. ${ }^{1}$

${ }^{1} \mathrm{On}$ the development of the fairy tale as a genre in Europe, see Bacchilega, 
As a lover of light reading and an avid consumer of fluff, I am drawn to literary fairy tales - however hybrid they may be, still they offer comfort through the certainties of formulas. The best of them are flimsy yet filling, airy and at the same time satisfying. No wonder some call light reading "popcorn." Like Italo Calvino-si parva licet_-"I have come to consider lightness a value rather than a defect." Unlike Calvino, however, I do not find it so easy to draw a meaningful distinction between thoughtful lightness and its frivolous counterpart (Calvino, 3, 10). There is delight in reading repetition and consolation in multiple returns of the same. And the happy ending is for us lovers of lightness an experience whose reappearance is never quite enough.

Though Calvino does not mention him in his lecture on literary lightness, Guido Gozzano (1883-1916) may be described in many ways as a poet of lightness, a poet fascinated by light things. Like other turn-of-thecentury Italian writers primarily known for a more weighty literary production addressed to adults, Gozzano best expressed his light approach to prose texts in the fairy tales he wrote for children. He published twentyfive of them: first, between 1908 and 1914, in the periodicals Il corriere dei Piccoli and Adolescenza, and later in the collection I tre talismani (1914), and La principessa si sposa (published posthumously in 1917); both collections enjoyed a certain popularity among young readers throughout the twentieth century. Gozzano's fairy tales are influenced by Italian classics of the genre such as Gian Francesco Straparola's Le piacevoli notti (15501553 ) and Giovan Battista Basile's Lo cunto de li cunti (1634-1636), as well as by European masters of the fairy tale such as the Grimm brothers, Hans Christian Andersen, and Charles Perrault. ${ }^{2}$

Gozzano's fairy tales evidence a taste for repetition and for symbolism (particularly number symbolism and the number three above all others), a historical setting that is vaguely medieval and a geography that is distinctly exotic, a careful choice of names for people and places, and a marked preference for fantastic characters such as fairies and talking animals, and for magical events like curses and enchantments. In common with much of Gozzano's poetic production, his fairy tales display a fascination with the caducity of things and hence with the ephemeral world of childhood and adolescence. Outside of time and beyond history, the world of fairy tales is

Bottigheimer, Canepa, Tatar, and Zipes, Why Fairy Tales Stick and When Dreams Came True.

${ }^{2}$ On Gozzano's fairy tales in their historical context, see Boero and De Luca, Di Gioia, Sebastiani. 
that world of eternal youth that Gozzano can only dream about in his poetry, permeated as it is with the fear of old age. ${ }^{3}$

Gozzano's poetry has been described, most notably by Eugenio Montale, as prose-like. ${ }^{4}$ Conversely, Gozzano's unique contribution to the late nineteenth- and early twentieth-century popular genre of the literary fairy tale is a permeating poeticity: Gozzano "'attraversa' la fiaba e la sottopone a procedimenti di impreziosimento linguistico, adotta la forma popolare e la riveste di squisitezze linguistiche" (Boero and De Luca, 108); or, in another critic's words, "La struttura ritmico-sintattica delle fiabe, musicata da assonanze, allitterazioni, geminazioni e ripetizioni, ripropone la stessa cadenza e musicalità delle liriche gozzaniane" (Di Gioia, 168). Gozzano's oeuvre in general seems to display an affinity with the genre of fairy tales: "L'opera di Guido Gozzano ha un sapore fiabesco" (Osella, 137). And so, in an essay dedicated to the fairy tale motif in Gozzano's poetic works, we read that his predilection is motivated by a variety of causes: a romantic sensibility with its essential discontentment, its sense of lack; a neoclassical desire for a distant, happy age; turn-of-the-century fascination with folklore and popular rhymes and narratives; a dreamy approach to autobiography and the past (Carletto, 95-97).

Considered a minor part of Gozzano's literary production, his fairy stories have not received all the critical attention they deserve-particularly in English, as no translation of the tales, to my knowledge, is available in print. Rather than as a superficial occupation dictated by financial motivations alone, however, Gozzano's fairy tale "Piumadoro e Piombofino" deserves to be viewed as a literary work in its own right, a work written within a genre discovered not too many years before as proving most appropriate for children. Within the late nineteenth-and early twentiethcentury canon of children's literature, "Piumadoro e Piombofino" is the image of lightness in both style and story, an airy narrative that flows through the reader's imagination much like its protagonist floats through the air.

In terms of its narrative, "Piumadoro e Piombofino" is lightened by

3 For more on the connections between Gozzano's fairy tales and the rest of his literary production, see Carletto, Sebastiani, and Vianello. Sebastiani concludes that, "i 'passaggi' dal mondo delle fiabe al mondo poetico di Gozzano interagiscono in una sorta di singolare partita di reciproco dare-avere" (19). Vianello points out that fifteen out of Gozzano's twenty-five fairy tales were published in the same year as I colloqui, 1911.

4 "Egli era nato per essere un eccezionale narratore o prosatore in versi" (Montale, 58). 
being divided into six, very short numbered sections: for the sake of interpretive lightness, I will follow these six sections as the thread for my reading of the tale.

I.

"Piumadoro e Piombofino" first appeared in the periodical $I l$ Corriere dei Piccoli on 25 July 1909-the first of Gozzano's fairy tales to be published in this popular children's publication. The story obeys from its inception the rules of its genre, with a setting that remains vague in terms of both time and place: the time is perhaps not now and the place may be elsewhere, but that is about all we know. The protagonist's character is not developed in depth, and her name, like Cinderella's and Snow White's, barely describes her spirit-focusing instead on her bodily circumstances: golden haired and, we later discover, light as a feather. Curiously, she is named Piumadoro (Goldenfeather) from the beginning of the tale, but she becomes light only in the second part. While Snow White is named after her looks at birth and Cinderella is the nickname for a girl who ends up spending too much time among the cinders of the fireplace, Piumadoro's name, the one she introduces herself with, presages her fate fourteen years before destiny baptizes her in deed as well as in words.

Piumadoro is poor but beautiful and kind; her looks and her heart distance her as much as possible from her weighty, black-stained origins in a family dedicated to the production of charcoal. The reader, no matter how young, can easily imagine that the girl's compassion to natural beings, repeated three times at the beginning of the tale, will most certainly return in the narrative and be adequately rewarded.

In these three encounters with the lightest of creatures (all gifted with poetic names: Pieride del Biancospino, Achenio del Cardo, Cetonia Dorata, names that appear repeatedly in Gozzano's poetry, as well), the girl has power of life and death over each, and when each being begs her to let it go, with the identical words ("Lasciami andare, per pietà!"), three times Piumadoro complies. She is thanked with the same complimentary words and the same personal question, three times: "Grazie, bella bambina. Come ti chiami?" The butterfly, the dandelion puff, and the rose beetle reveal a literary fondness for assonance and must learn the girl's name in order to reciprocate her benevolence. The narration, in turn, makes good use of the repetition of the girl's name, which holds, within its airy sounds, the protagonist's entire story of lightness: the name Piumadoro appears eleven times in this first short section alone.

Each weightless creature then announces its mission-always taking 
place in a nameless, distant geography, "in terra lontana": the butterfly must lay its caterpillars, the dandelion puff its seeds, the rose beetle must find faraway roses. Each of them promises Piumadoro a possible recompense, with the same words, "Un giorno forse ti ricompenserò." Then each being reinforces its lightness with one last buoyant, alliterative action: "volò via."

The taste for repetition so common in fairy tales makes a prominent appearance at the very beginning of this one. It confers on the tale a sense of ritual and mystery and it removes the tale from the everyday reality of things done just once-for three coincidences are just too many for real life, and for real time: surely temporality is transcended in this economy of superabundance, of excess. At the same time, the significance of the action is highlighted: how could anything not mean much, if it happens three times over? Even the youngest of readers, if they have an ear for such stories, will expect more: three may be too many, but it is not enough.

In addition to placing "Piumadoro e Piombofino" within the genre of the fairy tale, repetition establishes its poeticity. Three different kinds of repetition in poetry have been described: repetition of the sign (that is, of words and phrases), repetition of the signifier (alliteration, assonance, rhyme, and such), and repetition of the signified (synonyms and pleonasms; Cohen, 413-422). Gozzano's tale employs all three types, and does not limit itself to the kind of repetition typical of fairy tales: words and phrases are certainly repeated, but also alliteration ("per pietà," "bella bambina," "volò via"), as well as, beginning in the second section, frequent rhymes, and the many pleonastic reminders of Piumadoro's plight.

The three beings Piumadoro encounters are similar-all three light as can be, all three prone to flying, all three caught and released, all three promising a recompense-but one of them is fundamentally different. While the butterfly and the rose beetle are animals, insects caught by Piumadoro while they were resting on flowers, the dandelion puff is itself part of a plant; it belongs to the vegetable and not the animal world. Unlike the bugs, the puff is inanimate and wholly at the mercy of the wind for its physical displacements. This difference at the heart of repetition returns later in the story and defines the type of repetition enacted in "Piumadoro e Piombofino": for just as one cannot step into the same river twice, so also repetition, this story insists, never brings quite the same effect. The accumulation of meaning caused by repetition itself, for one, does not allow for the significance of subsequent instances to be identical to the first: "there is no repetition without difference and no difference without repetition, and each can only be discussed in terms of the other" 
(Rimmon-Kenan, 153).5

II.

In the second section comes the premise of this tale, that which impels the action and names both protagonist and story: a magic spell that makes Piumadoro increasingly light. At first it is fun to be "come un foglio di carta" and to let herself float down from the highest of tree branches; but soon Piumadoro cannot be allowed out of the house lest she should inadvertently fly away, lest she should abandon the nonno whose sole reason for living is Piumadoro. The four stones her grandfather attaches to the corners of her skirt no longer suffice in keeping her down, but this grandfatherly attachment, protectively paternal and, however subtly, jealously sexual too, stunts Piumadoro's growth. If, as Calvino says, "the weight of living consists chiefly in constriction" (Calvino, 7), then Piumadoro's lightness frees her from even the most useful of constraints: unable to stay put, she literally cannot be held down. She belongs elsewhere, physically and socially, and this the mysterious voice singing within her confirms.

The repetition that lies at the heart of fairy tales operates not only within each story-with the recurrence in fairy tales of magical beings, incantatory sentences, and spellbinding situations-but also in the transmission of such stories: analogous tales recur in a variety of times and places. So also the notion and the name of a young woman made supernaturally light by an evil spell derive from the fairy tale of another Italian author best known for weightier tomes, the Sicilian verista writer Luigi Capuana (1839-1915). "Piuma d'oro" is the first tale told in Capuana's Il

5 Interpretations of the intersection between children's literature and literary criticism and theory may be found in Frongia, Jones, and Thacker. Despite the recent boom in the publication of both books for children (Frongia discusses this boom in the Italian context) and critical studies of children's literature and of fairy tales (important journals include The Lion and the Unicorn, Marvels and Tales, Children's Literature), most books written for children remain as marginal to the literary canon as their critical interpretations are marginal to literary criticism in general (though increasingly less so: the MLA now has a division on children's literature). In Italy, a possible exception is Pinocchio (see Sherberg's edired volume on Collodi's masterpiece). For an overview of children's literature in Italy since the late nineteenth century, see Detti; for a collection of essays on children's literature in Italy during fascism, the special issue of Quaderni d'italianistica 24.1 (Spring 2004). A lengthy bibliography on the field of children's literature can be found on line at http://io.uwinnipeg.ca/ - nodelman/resources/allbib.htm. 
raccontafiabe (1893). The central premise of Capuana's tale, I have discovered with an archaeologist's excitement, is in turn drawn from George MacDonald's Victorian novella, "The Light Princess" (1864), the Scottish clergyman's first and most comic tale for children, and among his most beloved.

MacDonald's tale is about five times as long as Capuana's and ten times longer than Gozzano's. Like Capuana's "Piuma d'oro," MacDonald's version features a royal protagonist afflicted with physical and emotional weightlessness - a peculiar lack of gravity, the double-entendre of which MacDonald's witty tale, unlike Capuana's and Gozzano's relatively graver ones, self-consciously exploits (in a critic's words, MacDonald's tale "legitimized children's literature by establishing a bond between innocence and irony," Billone, 136). Hence the royal parents' verbal sparring, with the mother complaining about her daughter's danger of being "light-headed," "light-fingered," and "light-minded," while the optimistic father points out that their daughter might also, and more positively, be "light-handed," "light-footed," and "light-bodied." MacDonald's corporeally light princess, unaffected by the physical force of gravity, laughs and laughs - she has no intellectual or spiritual gravity, she is so light. And she is incapable of taking anything seriously at all.

MacDonald's and Capuana's heroines are, like Gozzano's, victims of a spell that makes them unnaturally light. However, while MacDonald's princess is being punished for her father's mistake (he neglected to invite his own sister, estranged and evil, to his daughter's christening, and the spell she casts upon her little niece is her revenge) and Capuana's princess for her own mistreatment of an old woman who visits her house (the girl does not know the crone is an enchantress when she mischievously oversalts and over-peppers the old lady's food), there is no apparent meaning for the spell befalling Gozzano's humble protagonist-nor are we ever given one later in the tale. "Light Princess" and "Piuma d'oro" are both nicknames given the girls on account of their condition; Gozzano's protagonist is named Piumadoro at birth, as far as the reader can tell, long before the onset of her "weight problem": it is as Piumadoro that she introduces herself to the butterfly, dandelion puff, and rose beetle.

Gozzano's tale does with Capuana's what his poetry does with, for example, D'Annunzio's. These stories play with citations from older and more traditional fairy tales the way his poems play with citations from the established poems that preceded them. "Gozzano mette in bella evidenza i modelli, ma li dissacra, rimarcando la distanza incolmabile fra la propria poetica di rinuncia e quella che alimentava le fonti evocate," writes Andrea 
Ciccarelli about Gozzano's poetry (113). Mutatis mutandis, something similar may be said about Gozzano's tales. "Piumadoro e Piombofino" flaunts its debt to Capuana's "Piuma d'oro" in its very title, and yet both the elimination of the apostrophe and the addition of another protagonist, Piombofino, tell the reader that much has changed in the time and space between the two stories. In another critic's words, "While Gozzano argues that all writing is essentially rewriting, and that unique and original experiences are no longer accessible in the modern world, he also contends that this sense of novelty and distance can be experienced in a mediated, yet ultimately contradictory manner, through other people's words" (Della Coletta, 192).

"Dissacrare" does not carry quite the strong connotations that the English "desecrate" does, and if the latter might be too heavy a word for what Gozzano's story does with Capuana's, "dissacrare," to borrow Ciccarelli's term, well describes Gozzano's fairy tale poetics. For Gozzano's fairy tale does question the rules of the genre; and although it may frustrate what readers have come to expect of traditional fairy tales, by insistently dialoguing with other authors, his fairy tales help readers understand both what a fairy tale is and what novelties Gozzano has brought to the genre. In Ciccarelli's words again, it is as if Gozzano "cominci a sbozzare imitando palesemente per poi far risaltare meglio quanto è suo e cosa invece è di scuola" (117). So, for example, while in Capuana's tale we witness the magic spell when the visiting crone touches the self-centered protagonist with her stick and tells her, "Dove vado e donde vengo, / C'è la pioggia e soffia il vento. / Tu col vento ci verrai, / Con la pioggia te n'andrai," in Gozzano's tale on the other hand there is no spell to witness (though the grandfather repeats "Piumadoro, povera bimba mia, qui si tratta di un malefizio," he cannot explain what is happening), and no lesson to be learned about the causal connection between evildoing and punishment.

This is a fairy tale, however literary, and there must be a way out of the protagonist's unusual, if meaningless, predicament. The reader does not yet know what this solution is, but it must have something to do with the mysterious voice singing a rhyming song within the protagonist. To the undeserved punishment of an innocent heroine, there will be an unhoped-for solution and an incommensurable reward. It is the incommensurability of the reward for a profoundly innocent protagonist that effects a definite change in Gozzano's repetition of MacDonald's and Capuana's versions of the story of a light princess. He adds a social component to the tale that profoundly alters its message.

For MacDonald's and Capuana's protagonists are of royal blood and 
eventually marry someone from their own class: the happy ending for those two princesses involves a permanent solution to their weight problem and an appropriately (and, it is to be hoped, equally permanent) aristocratic marriage. Gozzano's Piumadoro, on the other hand, though beautiful as a queen, belongs to the lowest social stratus-in contrast with her bright and light name, the occupation of her family is a particularly heavy and dark-stained one. In addition to the return to a normal weight and a happy marriage, then, and as a reward for her kindness, wit, self-reliance, and endurance in the face of an adverse and undeserved fate, Piumadoro will climb from the lowest to the highest level of society: a charcoal maker by birth, she will become, with marriage, a queen. And it is she who saves her future husband, not the other way around.

III.

The third time that, in this story, Piumadoro orders her grandfather, "Soffiami, nonno," on a morning she feels lighter and more bored than usual (having shut her in the house, Piumadoro's nonno is now her sole source of pleasure), she finds him dead. But when the going gets tough, the tough get going: three days after her grandfather's death Piumadoro flies away on her quest-like the three light creatures she has helped out before: "Quello che sta compiendo Piumadoro è un viaggio iniziatico" (Casella, 120). The reader can scarcely be surprised by the return of the three helpers: in fairy tales, those who assist others with kindness and selflessness always end up on the receiving end, somehow, and this repetition of rewards is one of the pleasures of the genre.

Though she cannot control the blowing of the wind, Piumadoro selfconsciously opens the door to her house, well knowing that this will initiate her travels towards the solution of her weight problem. "One must be as light as a bird, not as a feather," Paul Valéry said (Choses tues, 1930), in a dictum quoted by Italo Calvino--who knew a thing or two about fairy tales (Calvino, 16). Piumadoro is both a feather, as her name states, and a bird because she has a consciousness and, at this point, the desire to fly. Or, to stay within the metaphors of the story, she is a plant and an animal, a dandelion puff and a bug, inanimate and animate at once. She repeats, with differences, the flight of her friends.

The direct mention of adolescence-almost a clinical term-comes as a surprise within a fairy tale. Certainly this genre commonly tells of rites of passage, of the protagonist's growth from child into adult, from boy or girl into man or woman. Rarely, however, is this transition presented in so 
descriptive an allegory and called with such a specific name: the Fairy of Adolescence. (Adolescenza is also the name of the periodical in which Gozzano first published some of his fairy tales, and the term "adolescente" recurs in his poetry.)

In fairy tales bodily change frequently represents puberty, the physical alterations that go along with becoming an adult. Adolescence certainly causes a change in Piumadoro and her physical transformation at the age of fourteen brings about all kinds of other changes: independence from family and old friends, the introduction to new and different friends, a desire to get away from all that represents her old life, the awareness of her vocation, of her future calling: quite literally, Piumadoro hears a song that invites her to a different life. Lightness is freedom, for Piumadoro (a freedom fraught with dangers, of course, but what freedom isn't?), while the weight of duty and responsibility evaporates with the death of its human representative: the old and charcoal-making grandfather. His love and protection, his possessiveness and his needs are weighty, and she is so light; he is a charcoal maker, and she holds the future of a queen.

In his essay on lightness Calvino does not refer to any specific fairy tale, but he does speak "of privation that is transformed into lightness and makes possible a flight into a real $\mathrm{m}$ where every need is magically fulfilled" (Calvino, 28).

Might Gozzano's be the tale of a girl unhappy with the filthy condition of a charcoal maker's grand-daughter, orphaned to boot; a girl who desires to leave the sooty weight of her social position behind and does so at the first opportunity? Her body, her entire self, wishes to leave: the grandfather must shut her in the house in order to keep her as his own, because he needs her in so many ways (even without establishing an overt psycho-sexual bond, the tale makes the excessive nature of his love explicit enough). And when the grandfather is dead and gone, there is nothing, there is no one to tie her down with stones at the corners of her skirt, locked doors, or jealously possessive affection. So Piumadoro, her light destiny inscribed in her very name at birth, leaves for a better world, an improved social position, and a life of true love with somebody her own age. Desire moves her, rushing her towards what she lacks. Without this quickness of desire, and its quickening, there would be no life and no story.

A related reading must arise when the subject of puberty-related excessive weight loss comes up. Anorexia, in the words of bioethicist Simona Giordano, is "a progressive pursuit of lightness" and it cannot be explained outside of it. The "value of lightness" in our society, "the contexts where lightness is often celebrated," must be understood in order to make sense 
of anorexia: lightness is a form of spiritual and moral elevation. By fasting one becomes light (as well as pure) and, through lightness, ascension becomes possible (Giordano, 3, 7).

When Piumadoro becomes light and her tethers are removed, the first thing she does is ascend upwards, away from huts and charcoal and towards the spiritual world of the heavens, of fairies and castles, towards a marriageable prince and his glorious isles. Piumadoro is not anorexic in any literal sense, for her relationship with food is never mentioned, while the story insists that the girl, despite her supernatural lightness, remains beautiful and looks healthy. Her weight loss is not of the visible sort. But she is becoming an adult woman, and thus other to a world whose female inhabitants are twice described as either girls (Piumadoro's friends and peers) or elderly neighbours. In the first paragraph of the tale we are told that "La bimba cresceva buona, amata dalle amiche e dalle vecchiette degli altri casolari" and, in section five, the first castle she flies over gives her the illusion of containing "volti di persone conosciute e sorridenti: le compagne e le vecchiette del bosco natio, il nonno che la salutava."

Are there no adult women in Piumadoro's native woods? If that is the case, then it is no wonder that she must go elsewhere to find out who she is supposed to become. And in order to go elsewhere, she must be otherwise: light like a butterfly, like a dandelion puff, like a beetle.

IV.

The named presence of the Fairy of Adolescence in Gozzano's tale spells out the allegorical meaning of Piumadoro's adventures. The girl is growing up-her weight problem begins when she is at the critical age of fourteen -and this maturing process entails renouncing the protection of a parental figure (her grandfather dies), as well as frivolous, carefree pastimes (being blown around the house). The passage into adulthood also involves the imposition of tests, sufferings, and realizations.

Along with physical changes, maturity implies readiness for love and life partnership with another adult: the Fairy responsible for Piumadoro's growth and change (the word "adolescence" means "growing up") shows her, with the help of a magic mirror, what her fate holds and who she is supposed to become and clarifies the origin of a voice, of a call, that Piumadoro has been hearing even before the Fairy's explanation. Mirrors represent self-knowledge, most commonly, and this particular mirror is not shy about its function: in it, Piumadoro sees her future.

Gozzano's most visible innovation with respect to both MacDonald's 
and Capuana's versions of the tale, in addition to the protagonist's utter innocence and humble social condition, is the parallel curse experienced by Piumadoro's future husband. The young man is not a free and strong individual conveniently equipped to rescue the distressed protagonist. He is her partner, her complement: as she grows light, so he grows heavy, and as she needs to regain a normal weight, so does he. She seeks to leave, through lightness, an all-too heavy condition, while his heaviness might be a response to the excessively light nature of life at court, and at court on a tropical island, of all places. The two will only be able to overcome their predicaments through mutual assistance: a kiss, that most reciprocal of touches, symbolic of sexual maturity and thus of achieved growth, of the passage from the intermediary stage of adolescence to full adulthood.

Yet, because of the nature of the curse, it is Piumadoro who must make the first move-aided by the Fairy of Adolescence, who we begin to suspect is the one who put her into this mess. Piombofino can sing to her and call her to him, and he can offer Piumadoro-a charcoal worker-the infinitely higher status of a queen. But he cannot go anywhere, much less kiss her from where he is. It is Piumadoro who must come to his rescue, and her own. Now free of her grandfather, who has abandoned her with his death according to a topos common in fairy tales-the "trauma of abandonment," Jack Zipes has called it (Why Fairy Tales Stick, 204) Piumadoro needs someone, and specifically an adult male, to take care of. In many traditional fairy tales, unexpectedly abandoned girls not only achieve independence, "but they also suggest that the dominant gender's survival is itself dependent upon the 'weaker' sex" (Bates, 48). ${ }^{6}$ Piumadoro saves Piombofino and in so doing she also saves herself.

Piumadoro and Piombofino are repetitions of one another. In their representation there is a repetition of the sign, of the signifier, and of the signified. Their names provide intense alliteration and thus repetitions of the signifier, beginning as they do with "Pium..." and "Piom..."--sounds that evoke one another with an alliterative connection that is profoundly ironic: "piuma," feather, and "piombo," lead, are the very icons of lightness and weight respectively, and "leggero come una piuma" is the opposite of "pesante come il piombo." (Though a popular children's riddle comes to mind: What is heavier, a pound of feathers or a pound of lead?)

The signifieds of the two names repeat one another as well, for both consist of a young person in the process of adolescential change- their dif-

${ }^{6}$ Bates details in her essay the adventures of the female protagonists of "Hansel and Gretel," "Peter Pan," "The Wizard of Oz," and "Alice in Wonderland." 
ference being gender, geography, and social class. As for signs, there are words and phrases that get repeated ad nauseam: Piombofino keeps saying "Oh Piumadoro, bella bambina—sarai Regina," and Piumadoro keeps hearing it, and indeed repeating it-so that on occasion the reader does not know who it is that is singing, whether it is Piombofino singing to Piumadoro or whether it is Piumadoro who is repeating, with her voice, what she hears in Piombofino's own.

The two young people share a name, a spell, and a voice-repeated yet changed, the same yet different. Their names, and their spells, like the conjunction in the story's title, link them even as they separate them: they are "Piumadoro $e$ Piombofino."

\section{V.}

Language, and especially repetitive language, is central to Gozzano's tale: the characters' alliterative names describe their curses, the utterance of kind words and a seven-times-sung rhyme determine their happiness. But language comes with the relentless mechanisms of its own undoing: the traces of its ambiguity, alluded to in the protagonists' analogous yet opposite names and in the uncertainties enveloping the ambivalent Fairy of Adolescence, are highlighted in this fifth section of the story, with the description of the three treacherous fairies in their castles.

Given three kernels of wheat by the Fairy of Adolescence, Piumadoro is instructed to drop each on top of the three castles she will fly over. From each of these castles an evil fairy will try to attract the floating girl with either threats or flattery. The first dangerous being is understood by Piumadoro to be the Multicoloured Fairy, inhabiting the Castle of Lies. This is a seemingly happy and attractive place, but it is forced by the Grain of Prudence to reveal its evil, physically repellent reality: the familiar, loving faces that fill it are but phantasms of a fearsome region. The treacherous third being is the Blue Fairy, and hers is the Castle of Desires: once dropped on it, the Grain of Wisdom shows the castle to be but a cave, and its fairy a witch. Prudence and Wisdom, the story tells, unmask the flattery of $\sin$ and the iniquity of the wicked. This allegory is clear enough: the beautiful turns out to be ugly, the good, bad, and only the prudent and the wise-qualities that come with age and experience, the tale assumes-are able to discern the reality behind the appearances. But the second fairy, the Green Fairy, is quite different from the two that follow and precede her: she inhabits an unnamed castle (an onomastic omission that cannot be ignored, given the importance of names in this tale), whose evil-looking inhabitants turn sweet and beautiful when touched by the Grain of 
Goodness. Why is this fairy so different from the other two, and goodness from prudence and wisdom?

While the first and the third castles are perilous sites masked by a skindeep beauty, the second castle, once straightened out by the Grain of Goodness, seems like a good place to be; the reader may wonder where is the harm in visiting it. Is the Green Fairy's just an ordinary, happy world, undesirable to Piumadoro because she is destined to far greater glory-liberation of a king, ascent to the throne? Is it just because Piombofino needs her as his saviour and queen that she may not stop here? Still, why is this second fairy listed amongst the three wicked beings that Piumadoro is to meet-or rather, avoid meeting? ("Una fata maligna" is the generic name the Fairy of Adolescence uses for all three of the castle-dwelling fairies.)

The difference of this castle from the other two is glossed over, for Piumadoro's journey, her quest, must go on. Yet, wet wonder once again whether the Fairy of Adolescence is telling the whole story, or whether her words' relation with reality is lighter than Piumadoro herself. Perhaps it is just that Gozzano here is abandoning the rules of the genre. The essential difference is not so much in the second fairy herself, but in the effects of each virtue. Prudence and wisdom are represented as intellectual, epistemological virtues: they increase Piumadoro's knowledge, but they do not change the world: they reveal reality for Piumadoro, but they are unable to modify it, and evil remains evil. The transformation resides only in Piumadoro's knowledge, for from ignorance of and attraction to lies and desires (common enough, particularly amongst the young), she learns to perceive their reality and is repelled by it.

Goodness, on the other hand, transforms the world: the evil of the second castle, unafraid to show its true face, is overcome by goodness, and changes in its presence. The difference in this repetition (even evil can change, and become good) is too radical to properly belong to a fairy tale, hence its strangeness. However, the traps of literary language prevent its homologation and the difference lingers on-as radical as ever, and masked only by the appearance of sameness: this too is a fairy, and hers, too, is a castle to be avoided.

\section{VI.}

Weightless Piumadoro, born among charcoal makers, effortlessly flies with bugs and flowers, while Piombofino's riches cannot prevent him from consorting with oxen and sinking ever deeper within the bowels of his castle. And not even the oxen, the strongest of the European work animals, are 
able to move him: heaviness brings immobility and lack of desire. Petrified as by the gaze of a Medusa, or perhaps, through a different metaphor, by the enormous responsibilities of his social position, Piombofino destroys his own wealth, epitomized by a mosaic floor the likes of which hutdwelling Piumadoro has probably never seen.

This up-and-down movement of Piumadoro-who floats up and away from her hut and is kept down by her grandfather, who soars away at his death and lands at the Fairy of Adolescence, then flies high and low over the three castles and the seas, and, finally, glides down to the Fortunate Isles-follows a rhythm that is itself poetically repetitive, like the language and the images of the tale. Piumadoro flies like other girls on the brink of womanhood also fly in Gozzano's poetry: in "Le due strade," for example (La via del rifugio), the poet and his "Amica" walk carrying "la triste che già pesa / nostra catena antica," their age and relationship metaphorized in weight ("pesa") and its shackles ("catena"); they meet Graziella, "l'adolescente" last seen as a little girl: as she mounts her bicycle the poet perceives "un battito d'ali ignote" and "un non so che d'alato," then the bicycle "volò, come sospesa," and finally the girl is far, because "vola vola la bicicletta." For Gozzano female adolescence, it seems, involves winged flight.

In this final section of the fairy tale repetitions old and new continue with their usual twists. As Piumadoro and Piombofino are mirror images of one another, the same yet reversed, so also the Fortunate Isles, Piombofino's place, are the opposite of the woods, Piumadoro's locality: the woods may be no fortunate place, but the Fortunate Isles (often identified in cultural texts with the Canary Islands) have brought no greater luck to their king. In this semi-imaginary geography of the same yet different, we detect Gozzano's taste for the exotic, the same taste which led him to travel to India on a healing journey not altogether unlike Piumadoro's-who also must travel in order to restore health and normality to a body no longer functioning as it should. ${ }^{7}$ (The water that Piumadoro must fly over, the water surrounding the Fortunate Isles, is reminiscent as well of MacDonald's light princess: she too is saved by water, for it is water-contrary to its usual effect of buoyancy - that restores physical and emotional gravity to the protagonist of MacDonald's tale.)

Immobile weight instead of flighty lightness, fine lead instead of a golden feather, tall palm groves and golden minarets rather than woods

7 For an in-depth analysis of the workings of Gozzano's travel writing, and particularly his representation of the Indian state of Goa within the genre of the epic, see the article by Della Coletta. 
destined for fuel; a comet, a young woman beautiful and majestic as a goddess, has taken the place of a charcoal maker. These transformations involve change and difference, to be sure; but in their repetition, and repetitiousness, they harness the power of similarity, as well. In the metaphors that make up Gozzano's tale, the young woman's lightness is other than the young man's heaviness, but they are the same, too: they are both growing up, touched by the Fairy of Adolescence and united by a kiss that will set them both free.

Piumadoro flies with the butterfly, puff, and beetle, light like them; but they are her servants in the end, conjuring the fabric, gems, and pageboys that preview and make possible her transformation into queen. Twice more in this section Piombofino repeats his rhyming song and the last time (the seventh in the tale) preludes the announcement of Piumadoro's appearance by astrologer Mastro Simone. Earlier called a "mago," Mastro Simone is an echo perhaps of the Scriptural Simon Magus-who, supernaturally light, levitated to impress the crowds and, at Saints Peter and Paul's prayers, regained his bodily heaviness and fell to his death. With this allusion to another exceptionally light being in the history of Western culture, Gozzano's tale nods at the deep connections fairy tales entertain with the most canonical of texts (the Christian Scriptures, no less), without, however, weighing down the narrative for young readers-most likely, at the mention of Mastro Simone, to only imagine yet another fantastic magical being who helps Piumadoro get what she deserves. For Piumadoro is other than, yet a repetition of, the other three visions of Mastro Simone: the Christian fleet returning from the Holy Land, a flock of migratory herons, a Venetian galley filled with ivory. Mastro Simone calls her a comet, and hails her as "Una stella che splende in pieno meriggio!"

Mastro Simone's list is especially chaotic, confirming the importance of repetition in the story and at the same time questioning its interpretation: butterfly, dandelion puff, and rose beetle have much in common, despite their differences; and the same is true for the three fairies and their castles; even Piumadoro and Piombofino, different though they may be, display striking analogies. However, Mastro Simone's sightings surely look like an odd list: the pleasure of exotic images-medieval ships, birds in flight, precious cargo-follows a poetic more than an intellectual logic. And it is with such poetic lightness, we are perhaps being told, that we should enjoy the whole tale, dwell on its musicality, relish the contradictions of "questa fiaba, così ricca di valore metaforico e così leggera nel linguaggio, nella capacità evocativa e nell'emblematicità dei personaggi, ma salvifica e aperta alla speranza, la speranza dell'amore" (Casella, 120). 
By the end of her adventures, Gozzano's Piumadoro changes little because, besides the needed reacquisition of her weight, she has little to change: unlike the light princesses in MacDonald's and Capuana's earlier versions, she does not need to reorganize her approach to life and her existential priorities. Piumadoro is nevertheless transformed through a series of choices the text presents, with subtleness and restraint, as exemplary: kindness to others (she frees the three beings she caught), the ability to listen (she takes seriously the song playing within her), a spirit of adventure (she opens the door to the wind at her grandfather's death), courage in the face of dangers (the three castles she flies over), and trust in the goodness of her future (she kisses the prince as foretold in the mirror). These may be the story's gentle lessons.

It is often said by the admirers of the genre that traditional fairy tales are not an escape from the world but one way of learning about the world, of understanding it and knowing it. Echoing Calvino, De Lauretis has written that "Le fiabe costituiscono un sistema di valori, di opposizioni, di parametri di comportamento, di modi di essere e di fare. La loro funzione non è consolatoria o di distrazione ma essenzialmente conoscitiva (da cui certo il costume relativamente moderno nella nostra civiltà di raccontarle ai bambini, di farne materiale educativo" (De Lauretis, 60). Fairy tales have an epistemological function and, in telling about this world's reality through another reality, they implicitly interpret life as well and help us make sense of it. This is how Gozzano himself saw fairy tales: "Pur nella loro invenzione, anzi proprio in virtù della loro invenzione, le fiabe per Gozzano sono vere: la loro perduta logica consente di interpretare veramente le azioni, i destini degli uomini" (Sebastiani, 12).

By the time Gozzano wrote his literary fairy tales, many had become tired of how explicit the epistemological function had become in children's literature; though often veiled in the language of traditional fairy tales, nineteenth-century fiction for the young was steeped in didacticism and the instillation of moral values. Popular children's stories such as Ida Baccini's and Emma Perodi's, and of course Edmondo de Amicis's Cuore, were heavy texts, intended to help children become Christian adults and patriotic Italian citizens-with varying degrees of success or literary merit. ${ }^{8}$ Few stories in the genre of children's literature display the lightness that makes Gozzano's tale such a pleasure to its readers, and a maze for its interpreters.

Like traditional fairy tales, "Piumadoro e Piombofino" feeds the imagination first: it is seemingly useless, unproductive, lacking gravity-in a

${ }^{8}$ On this topic, see Pincherle and Frongia. 
word, light. But Gozzano's is an intensely literary fairy tale, as well: its didacticism is constantly interrupted by doubt and ambiguity, repetition is questioned by significant differences, originality by clear intertextual debts, and its language never ceases calling attention to its own workings and its own uncertainties. The theme of the light princess, in Gozzano's incarnation, may be read as an allegory of the literary fairy tale as a genre, as a reflection on its necessary limitations and as an exploitation, but especially an exaltation, of its many joys.

It is a good thing that Gozzano's tales have been proposed anew to Italian readers, through the 1993 publication by Sellerio of the paperback collection Fiabe e novelline, but with its distinctively Sellerio navy-blue look, and despite Piumadoro's enticing flight depicted on the cover, Fiabe e novelline seems directed at the adults that make up the Sellerio readership, and not at children. Gozzano's tenderly ironic tales, perhaps, clash in too many ways with the harsher conducts today's children are used to through their encounters with television and other irresistible media. The little paperback may have found its grown-up aficionados, but, for children at the end of the twentieth century, it never became a bestseller.

For literary fairy tales are a difficult genre. And although "the hybridity and healthy self-consciousness of the literary fairy tale have persistently been held against it" (Knoepflmacher, 15), it is precisely through its linguistic mixtures and literary self-awareness that "Piumadoro e Piombofino" constitutes a lesson in reading. Gozzano's is a light lesson, of course, one that does not aim to provide a univocally didactic narrative of how life should be-he leaves that task to the many nineteenth-century children's books that had so eagerly taken it up. Rather, what Piumadoro's tale teaches is to tread lightly on this world, to look up as well as down, to beware of appearances but to enjoy them, as well; to listen and to explore and, especially, to embrace the inevitability of loss, growth, change.

These lessons, however, risk losing their lightness if taken too literally, too referentially; for the tale's lessons, Gozzano reminds us through repetitions of signifiers and of whole signs, are linguistic above all else: to understand one's name is to realize one's future, it is to accept the lightness of our name, and possibly of our future, through the pleasure of its sounds; to understand one's name is to learn about the other, the other who is different yet the same, the other whose fate is bound to our own in ways that may not be immediately apparent; to understand one's name is to learn the name of love, to seek it out despite dangers, to find it and cherish it, and to let oneself be changed by it. 


\section{WORKS CiTED}

Boero, Pino, and Carmine de Luca. La letteratura per l'infanzia. Bari: Laterza, 1995.

Bacchilega, Cristina. "Il viaggio di Calvino: Fiaba, racconto e mito." La Ricerca Folklorica 12 (1985): 27-32.

Bates, Laura Raidonis. "Sweet Sorrow': The Universal Theme of Separation in Folklore and Children's Literature." The Lion and the Unicorn 31 (2007): 4864.

Billone, Amy. "Hovering Between Irony and Innocence: George MacDonald's 'The Light Princess' and the Gravity of Childhood." Mosaic 37 (2004): 135148.

Bottigheimer, Ruth. "France's First Fairy Tales: The Restoration and Rise Narratives of Les facetieuses nuictz du Seigneur François Straparole." Marvels and Tales 19.1 (2005): 17-31.

Calvino, Italo. "Lightness." Six Memos for the Next Millennium. Trans. Patrick Creagh. London: Vintage, 1992. 3-29.

Canepa, Nancy. Out of the Woods: The Origins of the Literary Fairy Tale in Italy and France. Detroit: Wayne State University Press, 1997.

Capuana, Luigi. "Piuma d'oro." Il Raccontafiabe. Available on line at http://www.liberliber.it/biblioteca/c/capuana/index.htm

Carletto, Mario. "Per uno studio del motivo fiabesco in Guido Gozzano." Italianistica 4 (1975): 95-103.

Casella, Mirca. "Cercando Perelà: Divagazioni intorno alla leggerezza." La scienza gaia. Saggi sul riso. Ed. Emy Beseghi. Milan: Mondadori, 1998. 117-137.

Ciccarelli, Andrea. "Tra le file dei vili: Il viaggio mancato di Gozzano." $M L N$ 114.1 (1999): 106-125.

Cohen, Jean. "Poésie et rédondance." Poétique 28 (1976): 413-422.

De Donato, Gigliola. Lo spazio poetico di Guido Gozzano. Rome: Editori Riuniti, 1991.

De Lauretis, Teresa. "Calvino e la dialettica dei massimi sistemi." Italica 53.1 (1976): 57-74

Della Coletta, Cristina. "Transtextual Patterns: Guido Gozzano Between Epic and Elegy in 'Goa: La Dourada."' Italian Modernism: Italian Culture Between Decadentism and Avant-Garde. Ed. Mario Moroni and Luca Somigli. Toronto: University of Toronto Press, 2004. 191-217.

Detti, Ermanno. "Introduction." The Lion and the Unicorn 26.2 (2002): 143-149.

Di Gioia, Maria Luisa. "Le fiabe di Guido Gozzano." Annali - Sezione Romanza 31.1 (1989): 161-172.

Frongia, Terri. "Pedagogy, Aesthetics, and Humanism: The Three Muses of Italian Children's Literature Theory." The Lion and the Unicorn 19.1 (1995): 50-70.

Giordano, Simona. "Qu'un souffle de vent: An Exploration of Anorexia Nervosa." Medical Humanities 28.1 (2002): 3-8.

Gozzano, Guido. "Piumadoro e Piombofino." La danza degli gnomi ed altre fiabe. Available on line at http://www.liberliber.it/biblioteca/g/gozzano/index.htm 
—. "La via del rifugio." Tutte le poesie. Available on line at http://www.liberliber.it/biblioteca/g/gozzano/index.htm

Jones, Katharine. "Getting Rid of Children's Literature." The Lion and the Unicorn 30.3 (2006): 287-315.

Knoepflmacher, U.C. "Introduction: Literary Fairy Tales and the Value of Impurity." Marvels and Tales 17.1 (2003): 15-36.

MacDonald, George. "The Light Princess." Available on line at http://www.gutenberg.org/etext/697

Montale, Eugenio. "Gozzano, dopo trent'anni.” Sulla poesia Ed. Giorgio Zampa. Milan: Mondadori, 1997. 54-62.

Osella, Giacomo. "Le fiabe di Guido Gozzano." Lares 29.3-4 (1963): 137-144.

Pincherle, Silvia Blezza. Libri, bambini, ragazzi. Incontri tra educazione e letteratura. Milan: Vita e Pensiero, 2004.

Quaderni d'italianistica 25.1 (2004).

Rimmon-Kenan, Shlomith. "The Paradoxical Status of Repetition.” Poetics Today 1.3 (1980): 151-159.

Sebastiani, Gioia. "Postfazione." In Guido Gozzano, Fiabe e novelline. Palermo: Sellerio, 1993. 9-19.

Sherberg, Michael, ed. Approaches to Teaching Pinocchio and Its Adaptations. New York: Modern Language Association, 2006.

Tatar, Maria. The Hard Facts of the Grimms' Fairy Tales. Princeton: Princeton University Press, 1987.

Thacker, Deborah. "Disdain or Ignorance? Literary Theory and the Absence of Children's Literature." The Lion and the Unicorn 24 (2000): 1-17.

Vianello, Marco. "Le fate e gli gnomi: Perrault e Gozzano." Studi novecenteschi 29.63-64 (2002): 127-138.

Zipes, Jack. Fairy Tales and the Art of Subversion: The Classical Genre for Children and the Process of Civilization. New York: Rourledge, 2006.

- When Dreams Came True: Classical Fairy Tales and Their Tradition. New York: Routledge, 1999.

Why Fairy Tales Stick: The Evolution and Relevance of a Genre. New York: Routledge, 2006. 